\title{
Tocopherol and Plastoquinone Synthesis in Spinach Chloroplasts Subfractions ${ }^{1}$
}

\author{
JØRGEN SOLL, MONIKA KEMMERLING, AND GERNOT SCHULTZ
}

\author{
Institut für Tierernährung, Arbeitsgruppe für Phytochemie und Futtermittelkunde, Tierärztliche Hochschule, \\ D-3000 Hannover 1, Federal Republic of Germany
}

Received March 18, 1980

\begin{abstract}
Subfractions isolated from intact purified spinach chloroplasts are able to prenylate the aromatic moiety of $\alpha$-tocopherol and plastoquinone- 9 precursors. The biosynthesis of $\alpha$-tocopherol and plastoquinone- 9 is a compartmentalized process. The chloroplast envelope membranes are the only site of the enzymatic prenylation in $\alpha$-tocopherol synthesis whereas the thylakoid membrane is also involved in the prenylation and methylation sequence of plastoquinone- 9 biosynthesis. A very active kinase which forms phytyl- $P P$ is localized in the stroma. Phytol but not geranylgeraniol is the polyprenol precursor of the side chain of $\alpha$-tocopherol in spinach chloroplasts.
\end{abstract}

$\alpha$-Tocopherol $(\alpha \mathrm{T})^{2}$ plays an important role as a constituent of the chloroplast membranes and this compound has been shown to be synthesized within the chloroplast (1). The two methylation steps involved in $\alpha \mathrm{T}$ synthesis are specifically localized at the envelope membrane (2). Plastoquinone-9 (PQ-9, see Appendix) has not only a function as electron carrier between the two pholusystems which are localized in the thylakoids, but is also a constituent of the chloroplast envelope (Douce and Soll, unpublished data). These findings strongly suggest that the envelope is a carrier of other enzymes involved in PQ-9 and $\alpha \mathrm{T}$ synthesis, e.g., the enzymatic prenylation of homogentisic acid, either with a $\mathrm{C}_{45}$-polyprenol in the case of $\mathrm{PQ}-9$ or a $\mathrm{C}_{20}$-terpenol in the case of $\alpha \mathrm{T}$ synthesis. Homogentisate is an intermediate of the shikimate pathway which also occurs within the chloroplast (3).

The chloroplast envelope is a continuous boundary of two osmiophilic membranes, and galactolipid synthesis is located in this chloroplast compartment (4). The present

\footnotetext{
1 This investigation was supported by the Deutsche Forschungsgemeinschaft.

${ }^{2}$ Abbreviations used: $\alpha \mathrm{T}, \alpha$-tocopherol; SAM, $S$-adenosylmethionine, $\mathrm{PQ}-9$, plastoquinone-9; tlc, thin-layer chromatography; b.r., boiling range.
}

paper indicates that the envelope membrane is the main site of the enzymatic prenylation and methylation involved in $\alpha \mathrm{T}$ and $\mathrm{PQ}-9$ synthesis.

\section{MATERIALS AND METHODS}

\section{Radiochemicals}

$\left[\mathrm{Me}^{\left.-{ }^{14} \mathrm{C}\right] \mathrm{SAM}}\right.$ (sp act, $50 \mathrm{mCi} / \mathrm{mmol}$ ) was purchased from Amcrsham Buchler, Braunschweig, West Germany. $\left[{ }^{3} \mathrm{H}\right]$ Homogentisic acid (sp act, $8 \mathrm{Ci} / \mathrm{mmol}$ ) was labeled by the tritium exchange service of NEN Dreieichenhain and purified prior to use on tle system I. $\left[\gamma^{32} \mathrm{P}\right] \mathrm{ATP}$ in $2 \mathrm{M} \mathrm{LiCl}_{2}$ (sp act, $0.30 \mu \mathrm{Ci} / \mathrm{nmol}$ ) was a gift from Prof. Dr. H. Strotmann, Botanisches Institut, Tierärztliche Hochschule, Hannover, West Germany.

\section{Chemical Synthesis}

The geranylgeranyl- and phytyl-substituted methylquinols and quinones (see Appendix) were prepared from the corresponding methylquinol with transgeranyllinalool and isophytol according to Ref. (1). Me-6-SQ and Me-6- $\mathrm{SQH}_{2}$ (see Appendix) were synthesized from natural solanesol and the corresponding quinol by a procedure similar to that described previous by (1). Polyprenylpyrophosphates were prepared by the method of Joo et al. (5). Geranylgeraniol was synthesized in a modified Horner Wittig reaction from triethylphosphonoacetate and trans-farnesylacetone according to Refs. $(6,7)$. The structure was verified by mass spectroscopy and tlc on system III and IV by comparison with an authentic sample of geranylgera- 
niol, which is a gift from Dr. W. Hoffmann, BASF, Ludwigshafen, West Germany. 'The geranylgeraniol provided is a mixture of $70 \% E$ and $30 \% Z$. transFarnesylacetone was a gift from Dr. F. Weber, Hoffmann-La Roche, Basel, Switzerland.

\section{Thin-Layer Chromatography Systems}

Thin-layer chromatography system I: silica gel with benzene/MeOH/acetic acid, 45/8/4; tle system II: silica gel with propan-2-ol/ $\mathrm{NH}_{3} / \mathrm{H}_{2} \mathrm{O}, 6 / 3 / 1$; tlc system III: silica gel with petroleum either (b.r. $60-80^{\circ} \mathrm{C}$ ) $/ \mathrm{Et}_{2} \mathrm{O}$, $1 / 1$; tle system IV: silica gel impregnated with $10 \%$ $\mathrm{AgNO}_{3}$ in acetonitrile, solvent petroleum ether (b.r. $60-80^{\circ} \mathrm{C}$ )/acetone, $3 / 2$; tlc system $\mathrm{V}$ : silica gel with petroleum ether (b.r. $60-80^{\circ} \mathrm{C}$ ) $/ \mathrm{Et}, \mathrm{O}, 10 / 1$, tle system VI: cellulose impregnated with $7 \%$ paraffin in petrol (b.r. $100-140^{\circ} \mathrm{C}$ ), solvent acetone $/ \mathrm{H}_{2} \mathrm{O}, 85 / 15$; tle system VII: same cellulose plates as VI but solvent acetone $/ \mathrm{MeOH}, 2 / 1$. All thin-layer plates were precoated and purchased from Schleicher und Schüll (Germany).

All substances were cochromatographed with authentic samples and detected by either the uv quench at $254 \mathrm{~nm}$ or by spraying with $20 \%$ molybdatophosphoric acid in $\mathrm{MeOH}$ and heating at $120^{\circ} \mathrm{C}$ for $5 \mathrm{~min}$.

\section{Isolation of Broken Chloroplasts}

Broken chloroplasts were prepared from intact chloroplasts isolated as described in (8). The chloroplast pellet resulting from centrifugation of medium $B$ was suspended with a very small amount of distilled water (1 ml/5-10 mg chlorophyll) to shock them hypotonically. After $10 \mathrm{~min}$ the suspension was adjusted with medium $\mathrm{C}$ to a final chlorophyll concentration of not less than $1 \mathrm{mg} / \mathrm{ml}$. Media $\mathrm{B}$ and $\mathrm{C}$ were as reported in Ref. (8).

\section{Isolation of Chloroplast Subfractions}

Chloroplast compartments were isolated by fractionation of intact chloroplasts on a biphysic dextran gradient (9) followed by gentle osmotic shock and separation of envelope membranes and thylakoids on a sucrose gradient (10). Thylakoids were washed twice in medium $C$ prior to use. The top phase of the membrane fractionating gradient (10) was used as chloroplast extract (stroma). The ratio between the different amounts of protein is: stroma, about $50 \%$ of chloroplast protein, envelope, about $1-2 \%$, and thylakoid, about $50 \%$ of total chloroplast protein (11). Protein determinations were done by the method of Lowry.

\section{Reaction Mixture}

The complete reaction mixture contained the following if not otherwise defined: (a) Experiments with broken chloroplasts. Chloroplast suspension in medium $\mathrm{C}, \mathrm{pH} 7.6$ (quantitated prior to use); $20 \mu \mathrm{M}\left[{ }^{3} \mathrm{H}\right]$ homogentisic acid; $2.5 \mathrm{mM}$ $\mathrm{NaHCO}_{3} ; 100 \mu \mathrm{M} \mathrm{C}_{20}$-prenyl-PP; or $100 \mu \mathrm{M} \mathrm{C}_{20}$-prenyl$\mathrm{OH}$ plus $100 \mu \mathrm{M}$ ATP. Reactions were initiated by addition of polyprenyl- $P P$ or the corresponding alcohol and were incubated at $20^{\circ} \mathrm{C}$ for $80 \mathrm{~min}$. Light intensity in experiments with illuminated chloroplasts was 0.1 $\mathrm{J} / \mathrm{cm}^{2} \mathrm{~s}$. Aliquots $(100 \mu \mathrm{I})$ were taken at different times. The reaction was stopped with a mixture of $\mathrm{MeOH} /$ $\mathrm{CHCl}_{3}(500 / 250 \mu \mathrm{l})$ to give a monophasic solution. After $2 \mathrm{~h} 250 \mu \mathrm{l} \mathrm{CHCl}_{3}$ and $250 \mu \mathrm{l} \mathrm{H}_{2} \mathrm{O}$ were added. The mixture was shaken vigorously (12). The organic layer containing the prenylquinones was evaporated to dryness and subjected to chromatography.

(b) Experiments with chloroplast fragments. In experiments on $\mathrm{Me}-6$-prenyl- $\mathrm{QH}_{2}$ synthesis the reaction mixtures were: chloroplast subfraction protein in medium $\mathrm{C}, \mathrm{pH} 7.6 ; 20 \mu \mathrm{M}\left[{ }^{3} \mathrm{H}\right]$ homngentisic acid; 100 $\mu \mathrm{M} \mathrm{C} \mathrm{C}_{2 v}$-prenyl-PP; or $100 \mu \mathrm{M} \mathrm{C}_{20}$-prenyl-OH plus 100 $\mu \mathrm{M}$ ATP.

In experiments on Me-6-SQH $\mathrm{S}_{2}$ biosynthesis the concentrations were: chloroplast subfraction protein in medium C, pH 7.6;20 $\mu \mathrm{M}\left[{ }^{3} \mathrm{H}\right]$ homogentisic acid; 80 $\mu \mathrm{M}$ solanesyl-PP; or $80 \mu \mathrm{M}$ solanesol plus $80 \mu \mathrm{M}$ ATP.

The reaction mixture with $\mathrm{Me}-6-\mathrm{SQH}_{2}$ as precursor of $\mathrm{PQH}_{2}-9$ was: chloroplast subfraction protein in medium $\mathrm{C}, \mathrm{pH} 7.6 ; 70 \mu \mathrm{M}\left[\mathrm{Me}^{-14} \mathrm{C}\right] \mathrm{SAM} ; 100 \mu \mathrm{M} \mathrm{Me}-6-$ $\mathrm{SQH}_{2}$ used immediately after reduction of the corresponding quinone (1). Reactions were initiated either by addition of the polyprenyl component or by SAM and incubated at $20^{\circ} \mathrm{C}$ for $80 \mathrm{~min}$ in the dark. Aliquots $(100 \mu 1)$ were taken at different times. The reaction was stopped and the lipids extracted as described above.

\section{Chromatography of Labeled Products}

Unlabeled carrier substances (about $25 \mu \mathrm{g}$ ) identical to the expected labeled products were added to the extraction solution. All prenylquinols were oxidized by air for better purification before chromatography. Me-phytyl- and Me-geranylgeranyl- quinones were chromatographed on system $V$ and rechromatographed on system VI. Me-6-SQ and PQ-9 were first chromatographed on system $V$ and rechromatographed on system VII. Phytyl-PP was chromatographed on system II. For further details of the chromatography see (1, 13). The radioactive areas were scraped off the plates, dissolved in $2 \mathrm{ml} \mathrm{MeOH}$ and were counted in $5 \mathrm{ml}$ scintillation mixture (Quickzint, W. Zinsser GmbH, Frankfurt, West Germany) using a Packard liquid scintillation counter.

\section{RESULTS}

The prenylation of homogentisate involved in $\alpha \mathrm{T}$ and $\mathrm{PQ}-9$ synthesis was examined with broken chloroplasts and 
chloroplast subfractions, isolated from intact purified chloroplasts. Furthermore the methylation of $\mathrm{PQ}-9$ precursors is shown. The following reactions were tested.

\section{Tocopherol Synthesis}

$$
\begin{aligned}
& \text { Homogentisic acid } \stackrel{+ \text { phytyl-PP }}{\longrightarrow} \text { Me-6-PQH }, \\
& \text { Homogentisic acid } \stackrel{+ \text { phytol }+ \text { ATP }}{\longrightarrow} \text { Me-6-PQH }, \\
& \text { Homogentisic acid } \stackrel{+ \text { geranylgeranyl-PP }}{\longrightarrow} \text { Me-6-GGQH }, \\
& \text { Homogentisic acid } \stackrel{+ \text { geranylgeraniol }+ \text { ATP }}{\longrightarrow} \text { Me-6-GGQH } .
\end{aligned}
$$

\section{Plastoquinone Synthesis}

$$
\begin{aligned}
& \text { Homogentisic acid } \stackrel{+ \text { solanesyl-PP }}{\longrightarrow} \mathrm{Me}^{-6-\mathrm{SQH}_{2},} \\
& \text { Homogentisic acid } \stackrel{+ \text { solanesol }+\mathrm{ATP}}{\longrightarrow} \mathrm{Me}-6-\mathrm{SQH}_{2}, \\
& \mathrm{Me} 6-\mathrm{SQH}_{2}
\end{aligned}
$$

\section{Tocopherol Synthesis}

Figure 1 clearly indicates that the envelope membranes are able to catalyze the enzymatic prenylation of homogentisate with phytyl-PP to give $\mathrm{Me}-6-\mathrm{PQH}_{2}$ (reaction $\mathrm{A})$. When stromal and membrane fractions were combined the rate of $\mathrm{Me}-6-\mathrm{PQH}_{2}$ is not stimulated. The findings show that the enzymes of prenylation are bound to the envelope membrane. The incorporation rate was $26 \mathrm{pmol} / \mathrm{h} \times \mathrm{mg}$ envelope protein. In marked contrast to the envelope fraction, the prenylation activity was negligible in the thylakoid and stromal fraction (Fig. 1).

When phytol and ATP (reaction B) are used instead of phytyl- $P P$ the rate of synthesis of Me-6-PQH $\mathrm{PQ}_{2}$ is equal to that of phytyl-PP alone but for this reaction stroma protein is necessary (Fig. 2). In additional experiments with phytol and $\left[\gamma_{-}{ }^{32} \mathrm{P}\right] \mathrm{ATP}$ a kinase was found to be located in the stromal fraction. Thus, when $100 \mu \mathrm{M}$ phytol and 1 $\mu \mathrm{M}$ ATP (sp act $0.30 \mu \mathrm{Ci} / \mathrm{nmol}$ ) in a solution of $3.8 \mathrm{mg}$ stroma protein in medium $\mathrm{C}$ were incubated as described under Material and Methods, the conversion rate of phytol to phytyl- $P P$ was $1.5 \mathrm{pmol} / \mathrm{h} \times \mathrm{mg}$ stroma protein. Envelope or thylakoid membranes were not able to perform this reaction.

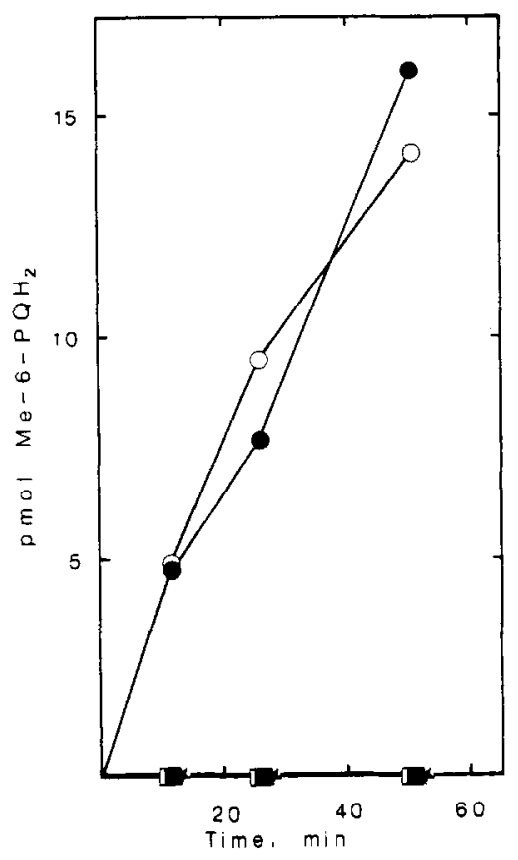

FIG. 1. $\mathrm{Me}-6-\mathrm{PQH}_{2}$ synthesis from $\left[{ }^{3} \mathrm{H}\right]$ homogentisate and phytyl-PP by different chloroplast subfractions and their recombinated systems. For further details see Material and Methods. Incubation mixture plus: (O), $+0.7 \mathrm{mg}$ envelope protein; $(\bullet),+0.7 \mathrm{mg}$ envelope protein $+0.9 \mathrm{mg}$ stroma protein; $(\square),+11.4$ mg thylakoid protein; $(\boldsymbol{D}),+5.7 \mathrm{mg}$ thylakoid protein $+0.9 \mathrm{mg}$ stroma protein; $(\star),+1.3 \mathrm{mg}$ stroma protein. 


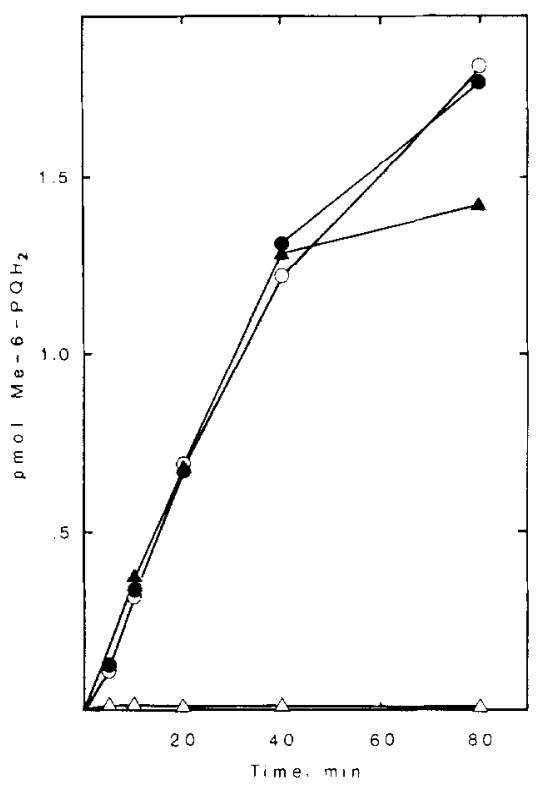

FIG. 2. Me-6-PQH ${ }_{2}$ synthesis from $\left[{ }^{3} \mathrm{H}\right]$ homogent;sate with phytyl-PP and phytol + ATP, respectively, by different chloroplast subfractions and their recombinated systems. For further details see Material and Methods. Incubation mixture plus: (O), phytyl- $P P$ $+0.54 \mathrm{mg}$ envelope protein; (O), phytyl-PP +0.54 mg envelope protein; $+0.5 \mathrm{mg}$ stroma protein; $(\triangle)$, phytol + ATP + 0.54 mg envelope protein; ( $\Delta$ ), phytol + ATP $+0.54 \mathrm{mg}$ envelope protein $+0.5 \mathrm{mg}$ stroma protein.

Both the prenylation and methylation were demonstrated either with broken chloroplasts (see Material and Methods) or with chloroplast subfractions. The prenyltransferase activity described above uses only phytol- $P P$ as precursor, but not geranylgeranyl- $P P$. In contrast, the methyltransferase shows a $3: 1$ preference for the geranylgeranyl-substituted derivative in the reaction Me-6-prenyl- $\mathrm{QH}_{2} \rightarrow 2,3-\mathrm{Me}_{2}-$ prenyl- $\mathrm{QH}_{2}$ (for details see $(2,13)$ ). When broken chloroplasts were incubated with $\left[{ }^{3} \mathrm{H}\right]$ homogentisate without exogenous polyprenyl- $P P$ only $\mathrm{Me}-6-\mathrm{PQH}_{2}(4.6 \mathrm{pmol} / \mathrm{h} /$ $\mathrm{mg}$ chlorophyll) and not $\mathrm{Me}-6-\mathrm{GGQH}_{2}$ was found. This result was supported by further experiments. When broken chloroplasts were incubated with $\left[{ }^{3} \mathrm{H}\right]$ homogentisate and geranylgeranyl-PP or geranylgeraniol plus ATP in the light and in the dark no increase in labeled $\mathrm{Me}-6-\mathrm{PQH}_{2}$ was found. This indicates that under the present condi- tions neither geranylgeranyl- $P P$ nor Me-6$\mathrm{GGQH}_{2}$ is reduced during the test. 'The relative high prenylation rate without exogenous polyprenol might be due to free phytol within the chloroplast. For the content of free phytol in leaves see Ref. $(14,15)$. In experiments with broken chloroplasts, $\left[{ }^{3} \mathrm{H}\right]$ homogentisate, and phytol- $P P$, neither Me-5-PQH ${ }_{2}$ nor $\mathrm{Me}-3-\mathrm{PQH}_{2}$ but only Me-6$\mathrm{PQH}_{2}$ was detected as labeled product after rechromatography on system VI. A light effect was observed in the control (Fig. 3). This indicates that not enough ATP is synthesized in the dark, while under illuminated conditions the concentration of endogenous ATP (synthesized by photophosphorylation) is high enough to reconstitute the synthesis of phytyl- $P P$.

\section{Plastoquinone Synthesis}

The alcohol involved in PQ-9 synthesis is solanesol, a $\mathrm{C}_{15}$-polyprenol (reactions $\mathrm{E}, \mathrm{F}$ ). The yield of $\mathrm{Me}-6-\mathrm{SQH}_{2}$ from homogentisate and solanesyl- $P P$ was lower than for the corresponding $\mathrm{Me}-6-\mathrm{PQH}_{2}$ synthesis. In this case the prenylation is not only due to the

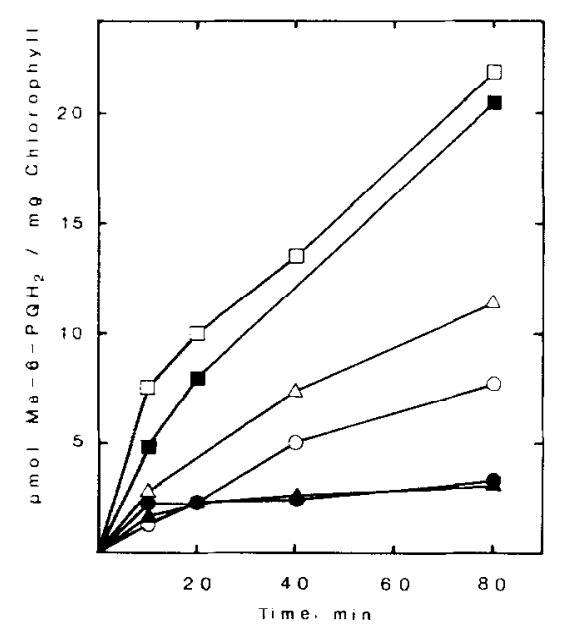

FIG. 3. Me-6-PQH ${ }_{2}$ synthesis from [ $\left.{ }^{3} \mathrm{H}\right]$ homogentisate without adding polyprenylalcohols, with phytyl$P P$ or with phytol + ATP by broken chloroplast in the light and in the dark. For further details see Material and Methods. Incubation mixture: $(0)$, in the light without polyprenylalcohols; $(\square)$, in the light + phytyl$P P ;(\triangle)$, in the light + phytol + ATP; $(\bullet)$, in the dark without polyprenylalcohols; $(\boldsymbol{\square})$, in the dark + phytyl$P P ;(\mathbf{\Delta})$, in the dark + phytol + ATP. 
envelope but also to the thylakoid membranes (Fig. 4). The conversion rate was 1.2 $\mathrm{pmol} / \mathrm{h} \times \mathrm{mg}$ envelope protein and 0.013 $\mathrm{pmol} / \mathrm{h} \times \mathrm{mg}$ thylakoid protein. Stroma protein had no enzymatic activity involved in the prenylation reaction (Fig. 4). When a recombinated system of envelope and stroma protein was used in experiments with $\left[{ }^{3} \mathrm{H}\right]$ homogentisate and solanesyl- $P P$ sometimes no incorporation in $\mathrm{Me}-6-\mathrm{SQH}_{2}$ was detected. This might be due to a phosphatase (Fig, 4). Under the present conditions as described under Material and Methods the chloroplast fragments and their recombinations were not able to form solanesyl- $P P$ from solanesol and ATP.

$\mathrm{Me}-6-\mathrm{SQH}_{2}$ was used as precursor to locate the methyltransferase activity to yield $\mathrm{PQH}_{2}-9$ (reaction $\mathrm{G}$ ). The envelope (10 $\mathrm{pmol} / \mathrm{h} \times \mathrm{mg}$ envelope protein) and also to a small extent the thylakoid membranes $(0.35$ $\mathrm{pmol} / \mathrm{h} \times \mathrm{mg}$ thylakoid protein) are able to catalyze the introduction of a methyl group from SAM into $\mathrm{Me}-6-\mathrm{SQH}_{2}$ to give $\mathrm{PQH}_{2}-9$ (Fig. 5). Stroma protein is again not involved. When stromal and membrane fractions (thylakoid and envelope membrane) were combined the rate of $\mathrm{PQH}_{2}-9$ synthesis was not stimulated (Fig. 5). These results are in good agreement with a previ-

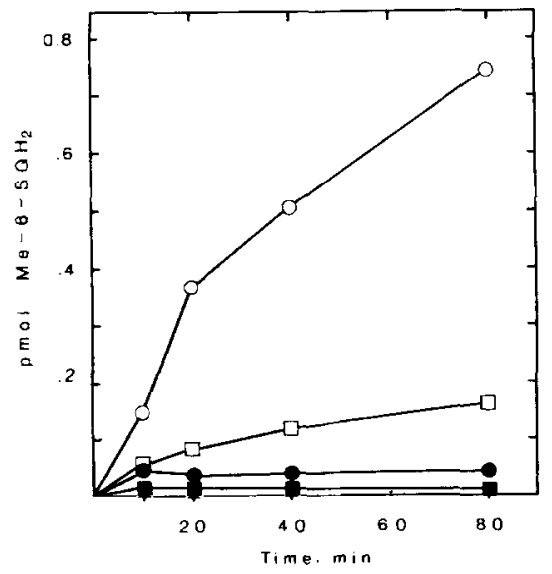

FIG. 4. Me-6-SQH ${ }_{2}$ synthesis from $\left[{ }^{3} \mathrm{H}\right]$ homogentisate and solanesyl-PP by different chloroplast subfractions and their recombinated systems. For further details see Material and Methods. Incubation mixture plus: (O), $0.65 \mathrm{mg}$ envelope protein; $(\bigcirc), 0.65 \mathrm{mg}$ envelope protein $+0.66 \mathrm{mg}$ stroma protein; $(\square), 5.8 \mathrm{mg}$ thylakoid protein; $(\square), 2.9 \mathrm{mg}$ thylakoid protein +0.66 mg stroma protein; $(\star), 0.66 \mathrm{mg}$ stroma protein.

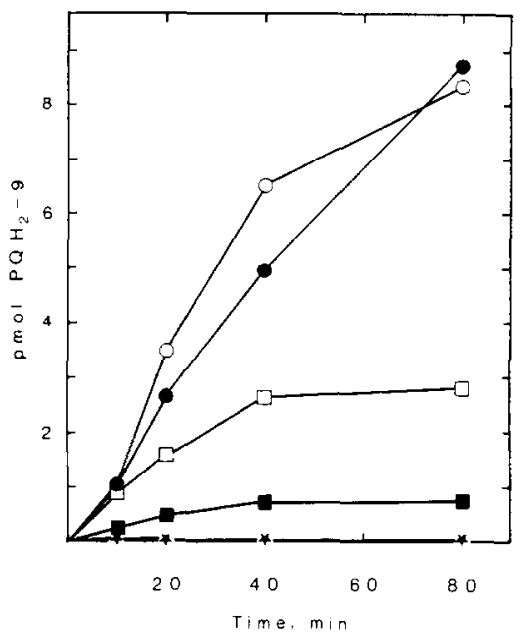

FIG. 5. $\mathrm{PQH}_{2}-9$ synthesis from $\mathrm{Me}-6-\mathrm{SQH}_{2}$ and [Me${ }^{14} \mathrm{C}$ SSAM by different chloroplast subfractions and their recombinated systems. For further details see Material and Methods. Incubation mixture plus: (O), $0.88 \mathrm{mg}$ envelope protein; $(\mathbf{0}), 0.88 \mathrm{mg}$ envelope protein $+1.4 \mathrm{mg}$ stroma protein; $(\square), 9.2 \mathrm{mg}$ thylakoid protein; $(\boldsymbol{\square}), 4.6 \mathrm{mg}$ thylakoid protein $+1.4 \mathrm{mg}$ stroma protein; ( $\star$, $1.4 \mathrm{mg}$ stroma protein.

ous report in which the methylation of $\alpha \mathrm{T}$ precursors is localized at the envelope membrane (2). A contamination of thylakoids by envelope membrane was not likely. They were washed twice prior to use and there was no contamination detectable in experiments on tocopherol synthesis.

\section{DISCUSSION}

The enzymes involved in $\alpha$-tocopherol synthesis are placed in the chloroplast envelope. The prenyltransferase and the methyltransferase activity are bound tightly to the envelope membrane. Furthermore the synthesis of geranylgeraniol and geranylgeranyl- $P P$ from isopentenyl- $P P$ is performed by a recombinated system of envelope or thylakoids plus chloroplast stroma (soluble protein) (12). The compartmentation of the synthesis of homogentisate from hydroxyphenylpyruvate is not yet clarified in spinach chloroplasts. Phytol should be originated from geranylgeraniol or its pyrophosphate by the reduction of three double bonds $(16,17)$. This reaction could not yet be demonstrated in chloroplasts and 


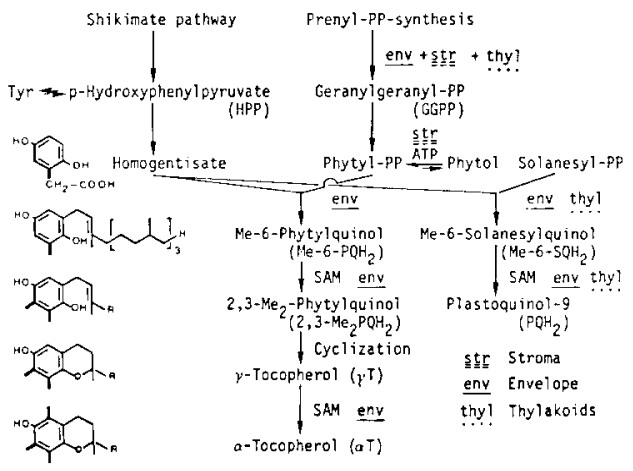

FIG. 6. Biosynthesis of prenylquinones in spinach chloroplasts.

chloroplast subfractions. Furthermore in the tocopherol synthesis, the cyclization of $2,3-\mathrm{Me}_{2}-\mathrm{PQH}_{2}$ to $\gamma \mathrm{T}$ was only detected in intact chloroplasts (1).

A very important result is the specificity of the prenyltransferase which uses phytyl$P P$ as polyprenyl component and not geranylgeranyl- $P P$. In the methylation of $\mathrm{Me}-6-$ $\mathrm{PQH}_{2}$ and $\mathrm{Me}-6-\mathrm{GGQH}_{2}$ a preference for the GG derivate was found $(2,13)$. In plants with a tocotrienol pathway (i.e., Hevea, wheat, barley (18)) geranylgeranyl- $P P$ may form the prenyl side chain and not phytyl- $P P$. The preference for the $\mathrm{Me}-6-\mathrm{GGQH}_{2}$ in comparison to $\mathrm{Me}-6-\mathrm{PQH}_{2}$ for the methylation step in higher plants like spinach might be an "ancient relic" while the really specific point developed during evolution became the enzymatic prenylation.

Furthermore, only one isomer among two or three possible ones is formed at each step in the biosynthesis of $\alpha \mathrm{T}$. As it was shown under Results, only $\mathrm{Me}-6-\mathrm{PQH}_{2}$ and not
Me-5-PQH $\mathrm{H}_{2}$ or $\mathrm{Me}-3-\mathrm{PQH}_{2}$ is formed by the homogentisate decarboxylasepolyprenyltransferase. In the following reaction the methyltransferase is specific to $\mathrm{Me}-6-\mathrm{PQH}_{2}$ (1). The resulting biosynthetic sequence and its compartmentation for $\alpha \mathrm{T}$ and $\mathrm{PQ}-9$ is shown in Fig. 6.

Plastoquinone-9 synthesis takes place at both the thylakoid and the envelope membrane. Stroma protein had no stimulating effect. The sequence of PQ-9 synthesis is similar to that of $\alpha \mathrm{T}$. First, homogentisate is prenylated with a polyprenyl- $P P$, in this case solanesyl- $P P$. Me-6- $\mathrm{SQH}_{2}$ is formed as only position isomer. It is methylated with SAM as cofactor to yield $\mathrm{PQH}_{2}-9$. A low enzymatic activity was found at the thylakoid membranes. Because of the high thylakoid to envelope protein ratio in the chloroplast (about 50:1(11)), the rate of PQ-9 synthesis by the thylakoids in total is not as different from the envelope ones as it is calculated on the basis of specific activity per milligram of protein. As confirmed under Results, a contamination of thylakoids with envelope membranes could be excluded.

The chloroplast envelope contains all the enzymes involved in the prenylquinone synthesis. This is important during the thylakoid biogenesis, because then massive biosynthesis of the two prenylquinones should occur at the envelope. $\alpha \mathrm{T}$ is needed as membrane constituent of the thylakoid, PQ-9 as electron carrier between the two photosystems in the thylakoids. Transport of $\mathrm{PQ}-9$ and $\alpha \mathrm{T}$ from the envelope to thylakoids may happen as membrane flow as proposed in Refs. $(4,19)$.

APPENDIX

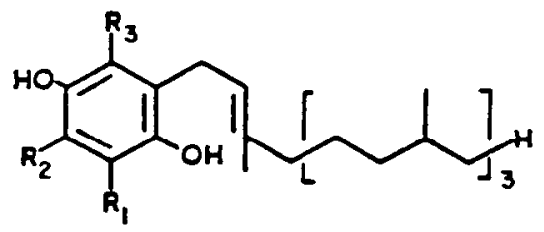

Phytylquinols

$\begin{array}{lllll}\mathrm{R}_{1} & \mathrm{R}_{2} & \mathrm{R}_{3} & & \\ \mathrm{CH}_{3} & \mathrm{H} & \mathrm{H} & \mathrm{Me}-6-\mathrm{PQH}_{2} & \text { 2-Methyl-6- } \\ \mathrm{H} & \mathrm{CH}_{3} & \mathrm{H} & \mathrm{Me}-5-\mathrm{PQH}_{2} & \text { 2-Methyl-5- } \\ \mathrm{H} & \mathrm{H} & \mathrm{CH}_{3} & \mathrm{Me}-3-\mathrm{PQH}_{2} & \text { 2-Methyl-3- } \\ \mathrm{CH}_{3} & \mathrm{CH}_{3} & \mathrm{H} & 2,3-\mathrm{Me}_{2}-\mathrm{PQH}_{2} & \text { 2,3-Dimethy1-5- }\end{array}$

phytylquinol 


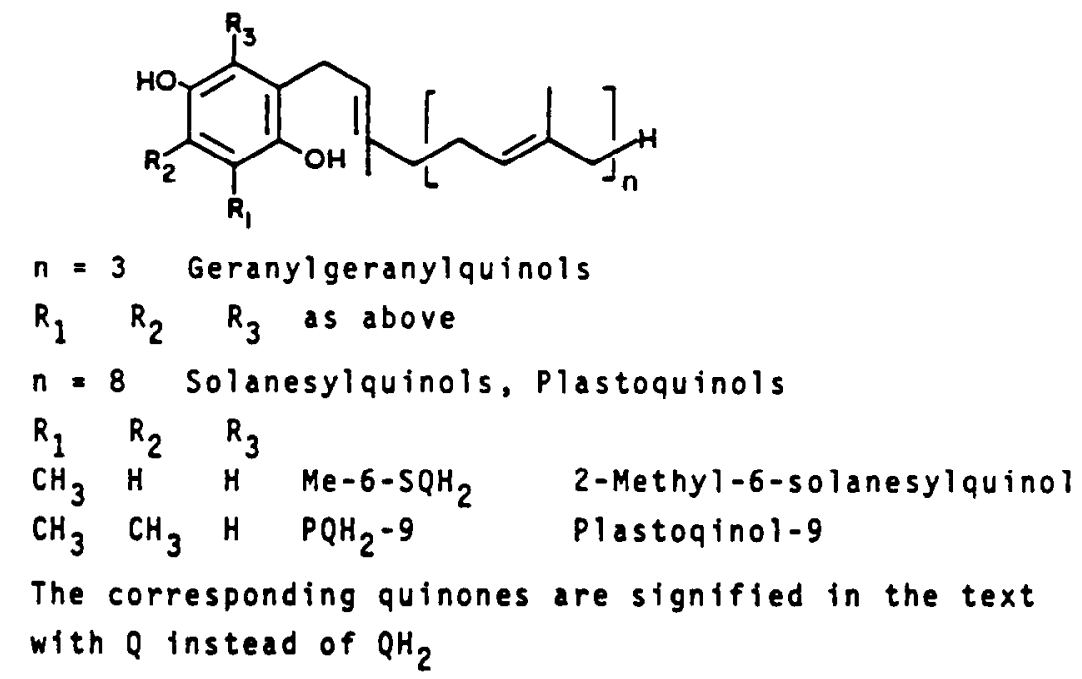

\section{REFERENCES}

1. Soll, J., ANd Schultz, G. (1980) Phytochemistry $19,215-218$.

2. Soll, J., Douce, R., AND Schultz, G. (1980) FEBS Lett. 112, 243-246.

3. Bickel, H., Palme, L., ANd Schultz, G. (1978) Phytochemistry 17, 119-124.

4. Douce, R., AND Joyard, J. (1979) Advan. Bot. Res. 7, 1-116.

5. Joo, C. N., Park, C. E., Kramer, J. K. G., anD Kates, M. (1973) Canad. J. Biochem. 51, $1527-1536$.

6. MAYer, H., AND IsLer, O. (1971) in Methods in Enzymology (Colowick, S. P. and Kaplan, N. O., eds.), Vol. 18c, pp. 241-248, Academic Press, New York.

7. Walter, W. M. (1967) J. Label. Compounds 3, $54-57$.

8. Jensen, R. G., AND Bıssham, J. A. (1966) Proc. Nat. Acad. Sci. USA 56, 1095-1101.

9. LARSSON, C. ANDERSON, B., AND Roos, G. (1977) Plant Sci. Lett. 8, 291-298.
10. Douce, R., AND JOYARD, J. (1979) in Plant Organelles (Reid, E., ed.), pp. 47 59, Ellis Harwood, Chichester.

11. Douce, R., AND Joyard, J. (1977) La Recherche 79, 527-537.

12. Block, M. A., AND Douce, R. (1980) Biochim. Biophys. Acta, in press.

13. Soll, J., AND Schultz, G. (1979) Biochem. Biophys. Res. Commun. 91, 715-720.

14. Karunen, P., ANd Liljenberg, C. (1978) Physiol. Plant. 44, 417-421.

15. WatTs, R. B., AND KeKwICK, R. G. O. (1974) Arch. Biochem. Biophys. 160, 469-475.

16. Costes, C. (1965) Phytochemistry 5, 311-326.

17. Wellburn, A. R., Stone, K. J., ANd Henning, F. W. (1966) Biochem. J. 100, 23c-25c.

18. Thompson, J. N., AND Hatina, G. (1979) $J$. Liquid Chromatogr. 2, 327-344.

19. MorRÉ, D. J., AND Mollenhauer, H. H. (1974) in Dynamic Aspects of Plant Ultrastructure (Robards, A. W., ed.), pp. 84-137, McGrawHill, London. 